\title{
Critical Play: Radical Game Design by Mary Flanagan
}

\author{
Cambridge, MA: MIT Press, 2009, 353 pp., £22.95, \\ ISBN 978-0-262-06268-8
}

\begin{abstract}
Suzanne Keller
THE PAST DECADE HAS SEEN A RAPID EXPANSION in the field of academic writing on the subject of computer and video games. The formerly marginalized field is now receiving its scholarly due as part of an increased focus on popular culture influenced by the development of Cultural Studies departments in universities. Early contributors to this scholarly field, such as Michel de Certeau and Dick Hebdige, have advanced popular culture as offering the potential for resistance and self-determination within overarching societal structures, while in recent years academic writers and the enthusiast press alike have upheld the notion that games are legitimate expressions of cultural production worthy of the same sustained interest and sophisticated analysis attracted by conventional written literature and visual art.

Clearly following this model is Mary Flanagan's Critical Play: Radical Game Design. This book builds on work the author completed for her doctoral research in the theory and practice of 'avant-garde game design' (p. 1). Much ground is covered in a little over 250 pages. Her wide-ranging interdisciplinary approach combines art history with sociology and media criticism, and filters it through the lens of play, looking at the ways that artists have used play as critique. She also discusses the ways that changes in toys and popular games have reflected changes in the society in which they were produced. This innovative reading traces the possibilities for social change through game-
\end{abstract}


playing as employed in art, and her argument seeks to demonstrate that these art-historical practices should be used in creating a new paradigm for criticallyengaged gaming that challenges and subverts the norms of the contemporary, commercially-orientated games industry.

With this text Flanagan seeks to illustrate her thesis that play, with its participatory nature, has been used by artists in order to critique regimes of power. The contemporary descendants of this lineage are the avant-garde computer games she speaks of. The structure of the book follows this line of argument, beginning with a definition of critical play, tracing its course through histories of art and popular culture, and ending with a manifesto of sorts, outlining the author's critical play method of game design.

The second chapter, 'Playing House', is a microcosm of the author's general approach to the material, laying out a discursive pattern that continues in subsequent chapters. It is thus beneficial to review this chapter's contents in detail as the structure of her arguments remains similar through the text. Here Flanagan describes how the domestic sphere and its representations have been deployed by artists and subverted by children. Artists, for example Bruegel, used depictions of the violent games of childhood to foreshadow the greater cruelties of adulthood and to reference the innate darkness in human nature. Later, in the European Enlightenment, images of playful, carefree domestic moments - as in the Rococo canvases of Jean-Honoré Fragonard-created a visual escape from Enlightenment rationality while signifying the emergence of a new leisure class in the contemporary milieu of eighteenth-century France. Dolls and varieties of domestic play, however, provide the chapter's main focus. In the Victorian era, she argues, domestic play was cultivated in young girls as a 'feminizing' influence, a way of encouraging the development of desired traits of material consumption and housekeeping efficiency. Yet girls often rebelled against the way they 'should' play, inventing new modes of play that overturned cultural conventions. Flanagan categorizes these ways of misbehaviour under three headings: unplaying (enacting forbidden scenes), redressing/reskinning (changing costumes or visual appearances), and rewriting (reinscribing player narratives onto traditional forms of play). These categories are repeatedly referenced through the text as means of clarifying the ways game players and game creators alike retool existing ways of play to fill their aims.

Perhaps the keyword is 'subversion', a term frequently used but often insufficiently defined. Although her definition of subversion initially satisfies, the potential for a truly thorough exploration of the potentialities of games is unfulfilled. Although the chapter 'Critical Computer Games' is especially rich in examples of social-critical computer programs (including, for example, the independently-produced 2008 release Hush, in which players take on the role of a Sudanese woman hiding from the Janjaweed militia), this promising thesis remains unproven. Certainly these games create awareness of real-world situations, but are experiences of these alternative game spaces translated into effective, lasting change? Subversion is defined as 'an action, plan, or activity intended to undermine an institution, event, or object' (p. 10). Does critical play extend beyond the time the box is shut, or the computer switched off? These questions, tantalizing and significant as they are, are left unanswered. 
Although its beginnings are promising, the text falters by trying to be too many things at once. Each chapter could easily be expanded into a book by itself. The chapter on 'Performative Games and Objects', for instance, bounces from Judith Butler to early twentieth-century Hollywood, through Dada, Surrealism, Gutai, Fluxus, and Japanese anime. The book's treatment of such art movements will hold few surprises for anyone with a grounding in art history: the playful characteristics of these artists have been well documented (although perhaps not as extensively as here), and one gets the feeling that greater insight would be provided by reading the cited sources themselves. Crucially, however, the text's freshness does increase, as it moves towards engaging with recent works of new media art and 'serious games' that use contemporary events as their source material.

As a synthesis, it is unsatisfactory. Yet this weakness also creates a fine text for general readers with no specialist knowledge of the area who do not require novel insights. Flanagan's text is most significantly useful as a resource for scholars, perhaps those working at the undergraduate level, to employ as a starting point for further research. There is no doubt that the author knows her topic. Her breadth of reference is admirable, and the constellation of resources used in composing this work might be usefully mined by anyone with an interest in the state of 'play' as it has been used by artists over the centuries. However, this dazzling and sometimes disorientating breadth is inevitably accompanied by a lack of depth in her critical analysis of these sources.

The field of critical game play and computer-aided play in particular is clearly significant and one looks forward to how scholars-Flanagan and others - will expand upon this critical play template.

University of Glasgow 